\title{
THE IMPACT OF PERFORMANCE ANALYSIS ON THE FINANCIAL MANAGEMENT AND CONTROL AT PUBLIC UNIVERSITIES IN BOSNIA AND HERZEGOVINA FEDERATION
}

\author{
Fuad ¿̌ergić* \\ Emira Kozarevic ${ }^{* *}$
}

Received: 18. 5. 2019

Review

Accepted: 18. 11. 2019

UDC: 336.13

DOI: https://doi.org/10.30924/mjcmi.24.2.10

\begin{abstract}
Organizations in today's extremely competitive environment need to devote significant time, energy as well as human and financial resources to the measurement of their efficiency, in order to increase their profit, reduce costs, better plan their assets and manage their budgets, as well as to improve budget controls and risk assessment. Therefore, they need performance models, including the Balanced Scorecard. Primarily intended for profit organizations, the Balanced Scorecard is today used in the public sector, as well. This paper presents the research into the utilization of the Balanced Scorecard in the public sector, examining whether the performance of higher education institutions may be improved by the design and utilization of the Balanced Scorecard model.
\end{abstract}

Key words: Balanced Scorecard, financial management and control, public sector

\section{INTRODUCTION}

The Balanced Scorecard is one of the most advanced and comprehensive business models currently used. It measures the efficiency of the most important factors affecting business success. Positive performance from the perspective of learning and growth should lead to the positive effect on internal business processes which should lead to the positive results from the customer perspective, which finally leads to the increase in financial resources (Yancy, 2014).

The significance of the Balanced Scorecard in a non-profit segment of the public sector is particularly evident. Profit organizations, indeed, have an almost perfect system of performance measurement. International accounting standards and international standards of financial reporting are completely dedicated to registering and presenting financial results, assets, and liabilities. As some parts of the public sector do not have profit in the forefront, the question arises how to measure success of such

\footnotetext{
Fuad Čergić, PhD student, Director of Economic Affairs, University of Tuzla, Tihomila Markovica 1, 75000 Tuzla, Bosnia and Herzegovina, E-mail: fuad.cergic@untz.ba, Phone: +38762 332483

** Emira Kozarević, PhD, Faculty of Economics, University of Tuzla, Univerzitetska 8, 75000 Tuzla, Bosnia and Herzegovina, E-mail: emira.kozarevic@untz.ba, Phone: +38761 178821
} 
organizations when it comes to spending public funds.

The main difference between the previously implemented systems of performance measurement and the Balanced Scorecard model is in the fact that the previous models used the indicators for the measurement of previous activities while the Balanced Scorecard model introduces the measures that serve for the assessment of future activities.

The aim of this paper is to show what is the use of the Balanced Scorecard at the public (non-profit) universities of Bosnia and Herzegovina Federation $(\mathrm{FBiH})$ and what are the expectations from its introduction from the aspect of financial management and control.

\section{LITERATURE REVIEW}

Anand, Sahay and Saha (2005) conducted a study in India related to the importance of key performance indicators divided into four perspectives of the Balanced Scorecard (Financial, Customer, Internal Business Process, and Learning and Growth). When it comes to the financial perspective, their results showed that the importance of measurement of return on investment is at $62.5 \%$, cash flow at $50 \%$, the same as for economic value added. This means that the Balanced Scorecard is a tool used for recognizing the areas for future improvement that were not recognized by other systems. Most of the informants in their study stated that the utilization of the Balanced Scorecard led them to recognize the possibilities for cost reduction in organizations, which resulted in the improvement of the low-level organizational units. Following the analysis of the theoretical aspects of the four perspectives, these authors designed the model for the utilization of the Balanced Scorecard in a public hospital in Romania. They identified the sources of data for financial and non-financial indicators required by the Balanced Scorecard as well as the specific goals for every single perspective. Finally, they established indicators, measurement procedures, goals and persons in charge of these goals. Their analysis showed that the public hospital management is rather specific as it requires the administration of complex activities with large consumption of resources in order to produce high quality healthcare services. These activities start with medical care provided for patients (clinical activities) and are followed by hotel services (accommodation and food) and efficient stock management (medications, medical equipment, laboratory reagents, etc.) combined with extremely limited financial resources.

Northcott and Taulapapa (2012) conducted research into how much the Balanced Scorecard is used in the public sector of New Zealand. The general awareness of the use of the Balanced Scorecard among managers is very high at $91.67 \%$, with a little more awareness among municipal councils of $94.60 \%$ compared to city councils of $81.81 \%$. Wilson, Hagarty, and Guthier (2004) conducted research into the results of using the Balanced Scorecard in the public sector. They find that organizations that offer more services and knowledge with less tangible desired outcomes make the implementation of the Balanced Scorecard more challenging.

This points to the importance of research in the public sector. The research presented in this paper is focused on higher education institutions as an essential part of the public sector, with the aim of design and utilization of the Balanced Scorecard model in financial management and control. 
The research conducted by Braam and Nijssen (2004) showed positive and negative relationships between the Balanced Scorecard and performance. The only possible explanation given for the negative relationship was that there was a lack of control during the research or inconsistent utilization of the Balanced Scorecard (McCaskill, 2012).

The results show that effort is allocated toward the areas that are reported. This suggests that individuals shift their effort from financial goals to non-financial goals when the management control system is comprehensive so as to monitor all goals (Ullrich, 2000).

Performance management is not a new concept in public policy. When ethics and values were emphasized in the 1960 s, performance management emerged. This included planning, programming and budgeting as a type of program evaluation. It was popular in the 1970s for measuring performance during audits and similar procedures. This process was known as performance audit to reduce costs and establish innovative governance (Heinrich, 2002). Wholey and Hatry (1992) state that "the process of using performance monitoring systems during budgeting and resource allocation, employee motivation, arranging performance-based procurement, improving public service delivery and improving communication between citizens and the country has begun."

\section{THEORETICAL FRAMEWORK}

Development of the Balanced Scorecard can be clearly divided into three stages or generations (Krunić, Unković, 2013). The first generation of the Balanced Scorecard simply used red, yellow and green reports on the achieved goals, which helped executive management to asses company's condition and turn to the key areas that require their attention. The first generation of the Balanced Scorecard came with the development of the software packages such as Gentia, Balanced Scorecard, Panorama Business Views and CorManage. These programs were designed as the resources for creating reports or "center console" to provide assistance in management. Although significantly advanced in relation to the simple initial stages, these were the first programs that integrated financial and nonfinancial reporting, thus providing the basis for today's integrated system of strategic management.

The second generation of the Balanced Scorecard created the relationship between strategic management and the measurement of effects by means of a strategy map. In the 1990s, Robert D. Kaplan and David P. Norton introduced a new model of performance measurement called the Balanced Scorecard, which provided a framework for organizing strategic goals in four perspectives (Kaplan, Norton, 2001):

- Financial,

- Customer (Stakeholder),

- Internal Business Processes,

- Learning and Growth.

Although the Balanced Scorecard is the type of the model designed to remove the disadvantages of the classic accounting measurements, it also has its own limitations. That is why the scholars in this field ask the following question: "Are the four perspectives enough?" They believe there is no mathematical formula that proves these four perspectives are required and sufficient. 
The third generation of the Balanced Scorecard comes as the process of evaluation. As the Balanced Scorecard evolved, it became obvious that it can be used not only to define the strategy but also to serve as the framework for implementation and strategic management.

Even though financial indicators are not in the forefront, the public sector should strive to provide high-quality services with the lowest cost possible. To that effect, the research problem reported on in this paper is how to design the Balance Scorecard model in the public sector so as to improve financial management and control. This improvement would then allow for the harmonization with legal regulations, performance measurement, rational spending of public resources, that is, the appropriate responsibility and good internal control systems.

\section{METHODOLOGY}

The data for this research came from secondary and primary sources. The research started with the secondary source data, i.e. literature review. The primary data were collected by means of a questionnaire. As the research was conducted in the sector of higher education in $\mathrm{FBiH}$, the questionnaire was distributed to the public universities via e-mail. The survey lasted from November 2018 to January 2019 and it included six public universities in $\mathrm{FBiH}$. Out of the total number of the universities surveyed, five universities replied, which gives a response rate of $83.33 \%$.

\section{RESULTS AND DISCUSSION}

Most public universities in $\mathrm{FBiH}$ are up to $80 \%$ centralized. This actually means that at these universities, management and control over certain activities or the entire institution are focused at the top of the hierarchical organizational structure. Initiative and work motivation starts from the very top of the organization but they also take full responsibility for the success of business activities. Only one of the surveyed universities is decentralized and its management, administration and all the other responsibilities are transferred from central to lower-level bodies.

In all $\mathrm{FBiH}$ public universities, a certain percentage of students pays the tuition, while others, more successful, pay only a small fraction of tuition. Since these are public universities, profit is not at the forefront, but since there is a decline in student numbers at all universities, finance is certainly important, and more attention must be paid to performance.

The level of control efficiency at a public university is different for different types of control. The least efficient are ex ante controls, aimed at the provision of legal regularity of financial and other decisions. These controls are made prior to the decisions on the usage of budget and other resources or before the business event. On a 1 to 5 scale, whereby 1 is "extremely low" adequacy and 5 is "extremely high" adequacy, these controls have the value of 3.6, which means that they are of medium adequacy. Ex post controls are aimed at revealing possible errors, irregularities or frauds. They are conducted after the business event is completed and are somewhat more efficient than ex ante controls. Their value is 3.8 , which means that they are also of medium adequacy (see Figure 1). The obtained data reveal that the enactment and implementation of the Law on Financial Management and Control enabled the utilization of budget and other resources at a high level when it comes to their proper, cost-effective, efficient and effective usage. 
Figure 1. Adequacy of controls and usage of budget resources

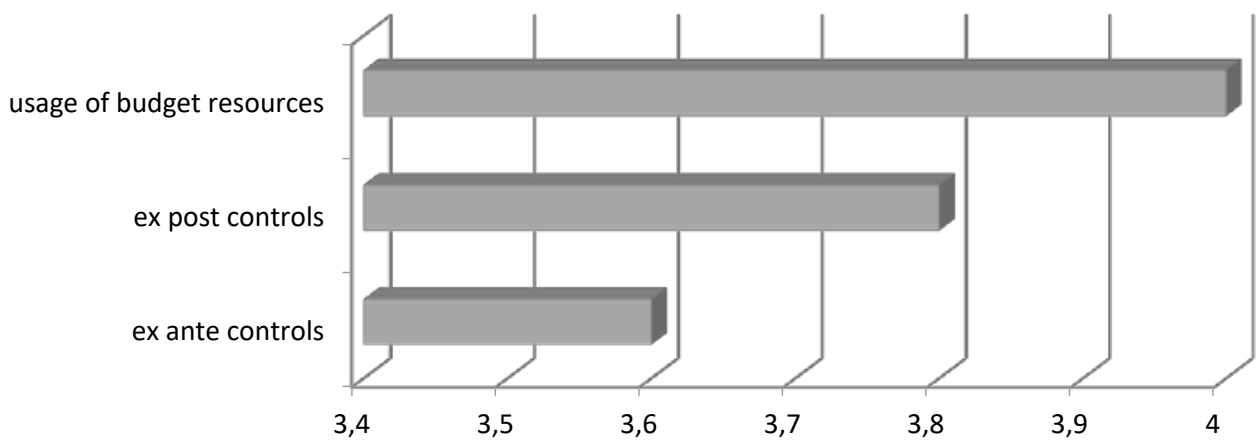

Source: Author

The results of the questionnaire on a 1 to 5 scale, whereby 1 is "extremely low" connectivity, 5 "extremely high" connectivity, have a value of 4 , which might mean (Figure 2) that there is a large effect on the protection of assets and liabilities as well as on financial reporting and monitoring business results. This actually means that the introduction of financial management and control serves for monitoring business results, financial reporting and as the protection against financial loss that might be the result of bad management, unjustified spending and use of resources. It can also contribute to better protection against irregularities, diversions, and frauds.

Figure 2 Effect of introduction of financial management and control on the protection of assets and financial reporting

financial reporting and monitoring business results protection of assets and liabilities

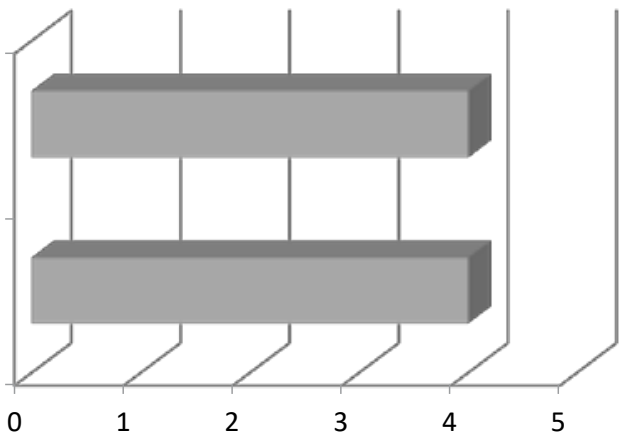

Source: Author

All the surveyed universities test user satisfaction by conducting various analyses and surveys, thus, examining the quality of teaching and education process. The most frequent ways to test user satisfaction are student surveys.
All the surveyed universities have the staff or departments in charge of the functioning of internal business processes, such as coordinators for financial management and control, departments or personnel for control, etc. The personnel or departments in charge of these activities at the surveyed 
universities are: quality manager, financial control manager, center for quality assurance, coordinator for financial management and control, etc.

The success of business and business processes is measured at all the surveyed universities. Three surveyed universities invest additional efforts in external and/or internal training and education of their staff (generally speaking) in order to further develop human resources. Some of the activities in terms of training program and education for the staff employed at the surveyed universities are given in Table 1.

Table 1. Activities/training programs and target groups

\begin{tabular}{|l|l|}
\hline Activity / program & Target group \\
\hline Public procurement seminars & Administrative staff \\
\hline Labor relations seminars & Administrative staff \\
\hline Accountancy seminars & Administrative staff \\
\hline Professional conferences & Teaching and administrative staff \\
\hline Fire protection training & All employees \\
\hline Professional seminars for legal department employees & Administrative staff \\
\hline Science conferences in the country and abroad & Teaching staff \\
\hline Student workshops & All \\
\hline
\end{tabular}

Source: Author

All the surveyed universities use some of the key performance indicators (KPI) and the main types and the intensity of their utilization are presented in Figure 3. It is evident that the most frequently used financial indicators are (1) the structure of expenditure and cost and the execution index with regard to the previous year and with regard to the Plan, and (2) cost per organizational units. Regarding other indicators, two out of five universities use cost price per student, efficiency of resource usage and effectiveness of resource usage.

Figure 3. Key performance indicators

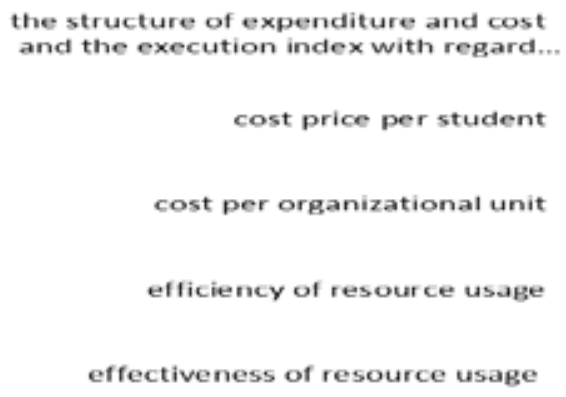

effectiveness of resource usage

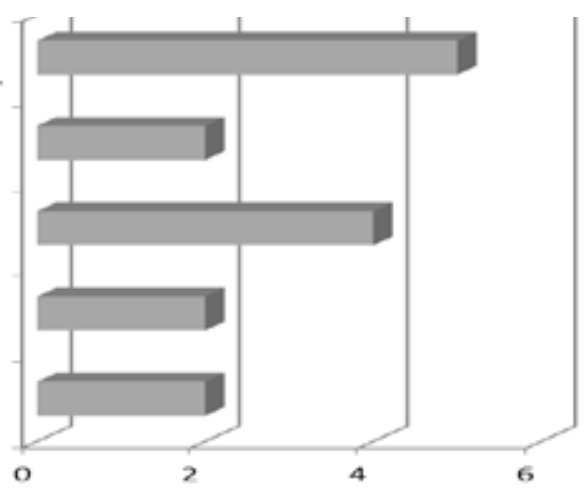

Source: Author 
Apart from the indicators of financial performance presented in Figure 3, these are also the indicators of business process performance, regularly monitored by the surveyed universities. These indicators are shown in Figure 4. It is evident that all the surveyed universities monitor the trend of student drop-out rates as well as the trend of the number of students. Also, students' assessment of the teaching staff is considered as one of important indicators of business process performance and is regularly monitored by the majority of the surveyed universities. What can be observed is the fact that none of the surveyed universities monitor the number of employees who terminate their employment contracts early.

Figure 4. Regularly monitored indicators of business process performance

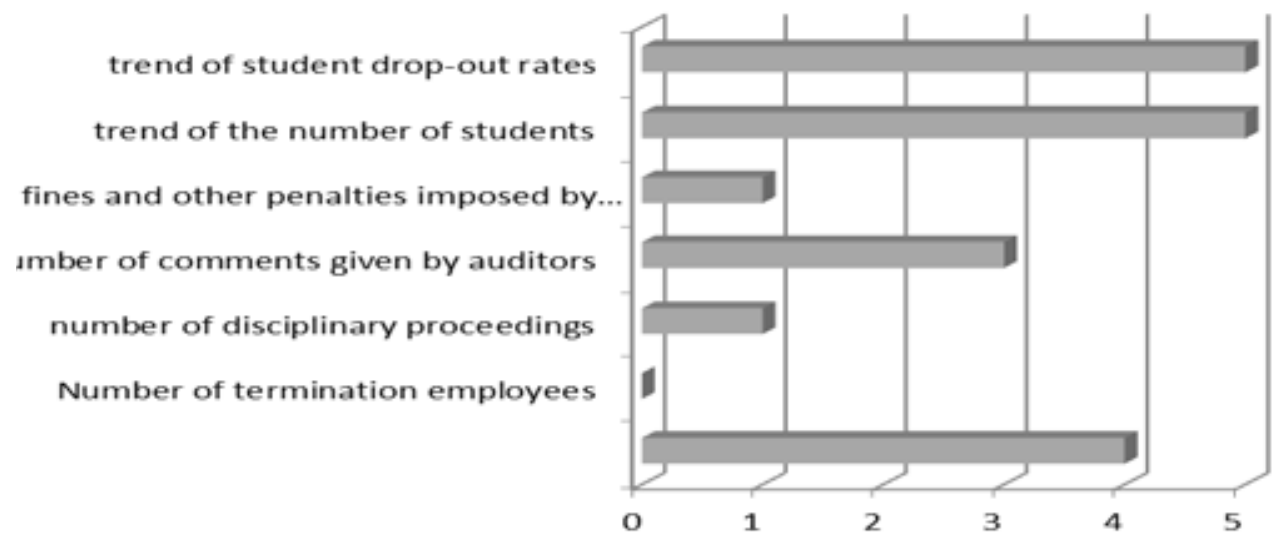

Source: Author

\section{CONCLUSION AND RECOMMENDATION}

Based on the conducted research, it can be concluded that none of the surveyed universities in $\mathrm{FBiH}$ implement the Balanced Scorecard although the Rulebook for Financial Management and Control at the institutions in $\mathrm{BiH}$ recommends it. However, all the surveyed universities believe that there should be a unified model or system within financial management and control that would be used for performance evaluation (assessment) and performance improvement (results) of higher education institutions. This would potentially "open the door" to the introduction of the Balanced Scorecard model. That is why additional research needs to be done for the purpose of designing the unified model and giving recommendations to the authorities regarding the changes of legal regulations that would require higher education institutions in $\mathrm{FBiH}$ to implement this model. After a successful implementation at higher education institutions, this model may be utilized in the remaining segments of the public sector.

The University of California, San Diego, was the first university to adopt the Balanced Scorecard and has utilized this model for 10 years. For example, the university housing department saves approximately $\$ 300,000$ a year by purchasing the material directly from the manufacturers (Martin II, 2011). There is considerable resistance to accepting the Balanced Scorecard within higher education as a strategic management tool. Those who criticize the Balanced Scorecard take the view that 
education does not imply the production of a competitive product such as a car, so this system cannot be applied because products cannot be measured easily. Such an opinion seems to contradict the logic that higher education institutions have the most educated staff and available administration, given that the Balanced Scorecard provides benefits in conducting a mission and strategic plan focused on measurement development (Martin II, 2011). However, the Balanced Scorecard is probably one of the most important accounting innovations of recent times (Braam and Nijssen, 2004).

\section{References}

1. Anand, M., Sahay, B. S. \& Subhashish, S. (2005). Balanced Scorecard in Indian Companies, Vikalpa, 30(2), pp.11-25

2. Braam, G. and Nijssen, E. (2004) Exploring the Antecedents of Balanced Scorecard Adoption as a Performance Measurement and Strategic Management System, NiCE Working Paper 08-115

3. Heinrich, C. J. (2002) Outcomes-based performance management in the public sector: Implications for government accountability and effectiveness, Public Administration Review, 62(6), pp. 712-725.

4. Kaplan, R. S. and Norton D. P. (2001) Transforming the Balanced Scorecard from Performance Measurement to Strategic Menagement: Part I, Accounting Horizons 15(1), pp.87-104.

5. Krunić, G. \& Unković I. (2013). Razvoj koncepta Balanced Scorecard kao sistema strateškog menadžmenta, Trebinje: Fakultet za proizvodnju i menadžment Trebinje
6. Martin II, C. (2011). The benefits of utilization of a quality scorecard in higher education. Doctoral dissertation. Faculty of California State University Dominguez Hills

7. Mccaskill, A. D. (2012). Exploring the Feasibility of Implementing the Balanced Scorecard in French Manufacturing Companies. Doctoral dissertation. Northcentral University

8. Northcott, D. and Taulapapa, T.M., (2012) Using the balanced scorecard to manage performance in public sector organizations, International Journal of Public Sector Management, 25(3), pp.166-191, https: //doi.org/ 10.1108 /09513551211224234

9. Ullrich, M. J. (2000). The effects of the Balanced Scorecard's information reporting system and economic incentives on effort allocation among multiple goals. Doctoral dissertation. University of South Carolina

10. Wholey, J. S. and Hatry, H. (1992) The case for performance monitoring. Public Administration Review 52(6), pp. 604-610. https://doi.org/ $10.2307 / 977173$.

11. Wilson, C., Hagarty, D., \& Gauthier, J., (2004) Results using the balanced scorecard in the public sector. Journal of Corporate Real Estate, 6(1), pp. 53-64. https://doi. org/10.1108/14630010410812234

12. Yancy, A. A. (2014). The Balanced Scorecard and Long-term Financial Performance: Evidence from Publicly Traded Companies. Doctoral dissertation. Faculty of Graduate School, University of Southern California 


\section{UTJECAJ ANALIZE PERFORMANSI NA FINANCIJSKO UPRAVLJANJE I KONTROLU U JAVNIM SVEUČILIŠTIMA U FEDERACIJI BOSNE I HERCEGOVINE}

Sažetak. Organizacije, $u$ današnjem, iznimno konkurentnom okruženju, trebaju posvetiti značajno vrijeme, energiju, kao i ljudske te financijske resurse mjerenju svoje učinkovitosti, kako bi povećale profit, smanjile troškove, bolje planirale svoju imovinu i upravljale budžetima, ali $i$ unaprijedile budžetsku kontrolu i procjenu rizika. U tom su smislu potrebni modeli organizacijskih performansi, što uključuje i uravnoteženu tablicu rezultata (Balanced Scorecard). Iako je, prvenstveno, namijenjena profitnim organizacijama, ova se metoda danas koristi i u javnom sektoru. U ovom se radu predstavlja istraživanje korištenja uravnotežene tablice rezultata (Balanced Scorecarda) u javnom sektoru, pri čemu se analizira mogu li se performanse institucija visokog obrazovanja unaprijediti dizajniranjem i korištenjem modela uravnotežene tablice rezultata (Balanced Scorecarda).

Ključne riječi: uravnotežena tablica rezultata (Balanced Scorecard), financijski menadžment $i$ kontrola, javni sektor 
